\title{
Література
}

1. Громыко Ю. В. Образование перестает быть гуманитарной технологией / Ю. В. Громыко // Вести Международного Соломонова ун-та. - 2000. - № 4. - С. 4-10. 2. Дзега В. Організаційно-методичне забезпечення вдосконалення професійної компетентності педагогічних працівників сільської школи на андрагогічних засадах / Володимир Дзега // Нова педагогічна думка : [науково-методичний журнал]. - 2013. - № 3 (75). - С. 36-40. 3. Иванютина В. Н. Формирование ключевых компетентностей учеников на уроках математики [Электронный ресурс]/ В. Н. Иванютина. - Режим доступа : http://festival.1september.ru/articles/416315/. 4. Коменский Я. А. Избранные педагогические сочинения [текст] : в 2 т. / Я.А. Коменский; под ред. А. И. Пискунова. - Москва : Педагогика, 1982. - Т. 1. - 693 с. 5. Компетентнісний підхід у сучасній освіті : світовий досвід та українські перспективи / за заг. ред. О. В. Овчарук. - Київ : К.І.С., 2004. - 112 с. 6. Лісіна Л. О. Формування професійної компетентності вчителя : [навч. метод. посібник] / Л. О. Лісіна, О. О. Барліт. - Запоріжжя : Лана-Друк, 2006. - 212 с. 7. Локшина О. I. Становлення компетентнісної ідеї в європейські освіті [текст] / О. І. Локшина / Реалізація європейського досвіду компетентнісного підходу у вищій школі України: Матеріали методолог. семінару. - Київ : Педагогічна думка, 2009. - 360 с. 8. Малихін О. Зміст і сутність самостійної навчальної діяльності студентів : історія і сучасність / О. Малихін // Українська мова і література в школах України. - 2014. - № 11. - С. 24 -27. 9. Олійник В. В. Стан та перспективи модернізації системи фахового зростання педагогічних працівників України / В. В. Олійник // Освіта на Луганщині. - 2002. - № 1 (16). - С. 11-14. 10. Попков В. А. Дидактика высшей школы : [учеб. пособие для студ. высш. учеб. заведений] / В. А. Попков, А. В. Коржуєв. - [2-е изд., испр. и доп.]. - Москва : Издательский центр «Академия», 2004. 192 с. 11. Савченко О. Я. Уміння вчитися - ключова компетентність молодшого школяра : [посібник] / О.Я.Савченко. - Київ : Педагогічна думка, 2014. - 176 с. 12. Стратегія реформування освіти в Україні : рекомендації освітньої політики. - Київ : К.І.С., 2003. 296 с. 13. Теорія і практика організації самостійної роботи студентів вищих навчальних закладів : [монографія]/ колектив авторів ; за ред. проф. О. А. Коновала. - Кривий Ріг : Книжкове видавництво Кирєєвського, 2012. - 380 с. 14. Хворостенко I. Розвиток самоосвітньої компетентності як психолого-педагогічна проблема / Ірина Хворостенко // Нова педагогічна думка : [науково-методичний журнал]. - 2013. - № 3 (75). - С. 137-140. 15. Чеботарева Е. С. Информационные технологии в развитии самообразовательной компетентности студентов [Электронный ресурс]/ Е. С. Чеботарева. - Режим доступа : http://ito.edu.ru/2008/kursk.html/

Наталія Самовілова

\section{ДОСВІД ЗАКОРДОННИХ УНІВЕРСИТЕТІВ У ПІДТРИМЦІ ВИРОБНИЧОЇ ПРАКТИКИ СТУДЕНТІВ}

Самовілова Н. О. Досвід закордонних університетів у підтримці виробничої практики студентів.

У статті аналізується закордонний досвід організації виробничої практики студентів та випускників, з'ясовуються іiі сутність та форми: стажування, віртуальне стажування, сендвіч-курси. Розглядається зміст підтримки майбутніх фахівців центрами розвитку кар'єри шляхом аналізу сайтів провідних університетів США. 
Ключові слова: виробнича практика, віртуальна практика, стажування, центри розвитку кар'єри.

Самовилова Н. А. Зарубежный опыт поддержки производственной практики студентов.

В статье анализируется зарубежный опыт организации производственной практики студентов и выпускников, выясняются ее сущность и формы: стажировка, виртуальное стажировки, сэндвич-курсы. Рассматривается содержание поддержки будущих специалистов центрами развития карьеры путем анализа сайтов ведущих университетов США.

Ключевые слова: производственная практика, виртуальная практика, стажировка, центры развития карьеры.

Samovilova N. A. The foreign experience of internship support of future specialists.

The foreign experience of internship of students and graduates is discussed, the internship nature and forms are examined: internships, virtual internships, sandwich courses. The support of future specialists by career development centers is investigated through analyzing the websites of leading US universities.

Key words: virtual internship, internship, career development centers.

Одним з головних складників підготовки професійно компетентного IT-фахівця у ВНЗ $\epsilon$ виробнича практика. Якісна організація виробничої практики допоможе студентам адаптуватися до вимог ринку, знайти своє місце у професії, бути конкурентоспроможними.

Різноманітні аспекти підготовки майбутніх фахівців 3 інформаційних технологій розглядалися в дослідженнях О. Глазунової, Ф. Ільясової, Т. Морозової, Л. Усеінової, Л. Курзаєвої, 3. Сейдаметової [1-3]. Проблеми виробничої практики 3 урахуванням специфіки виробництва за різними спеціальностями відображені в працях С. Батишева, М. Киньколіха, М. Пальчук, Т. Попової, В. Савченко, Ю. Сухарнікова, Л. Усеінової, К. Хорошун [6-7]. Але сучасний закордонний досвід організації виробничої практики не знайшов достатнього відображення в наукових джерелах.

Meта статmi - проаналізувати закордонний досвід організації виробничої практики, 3'ясувати її сутність та форми.

Як педагогічна категорія, практика (від грец. праксис - діяння, активність, діяльність) $\epsilon$ складовою частиною навчально-виховного процесу, мета якої - навчити студентів творчо застосовувати в майбутній діяльності отримані в результаті навчання науково-теоретичні знання та практичні навички, сприяти розвитку в майбутніх фахівців інтересу до науководослідної роботи у своїй галузі [5].

За кордоном терміну виробнича практика відповідає термін «internship» (стажування). Стажування розуміється як пов'язаний з майбутньою кар'єрою досвід в ході отримання ступеня бакалавра шляхом участі в роботі, яка планується та перевіряється відповідним чином [14].

Можна виокремити такі характеристики стажування:

- сприяє особистому та професійному розвитку студентів через розв'язання складних практичних завдань;

- завершується до випуску студентів 3 університету, хоча в деяких випадках стажування може бути завершеним влітку, після того, як студент отримає ступінь бакалавра i 
перед початком навчання за програмою наступного ступеня;

- планується шляхом консультацій з відділом коледжу чи університету, щоб сприяти отриманню корисного досвіду;

- передбачає наставництво та освітню компоненту;

- стажування доповнює знання, які отримані в класі;

- спеціальним чином оцінюється;

- спирається на відносини університету або коледжу з роботодавцями;

- $є$ найбільш успішним, коли студент, відділ / коледж і роботодавець - усі поділяють відповідальність за те, щоб студент отримав цінний досвід.

Близькими термінами в цьому полі $є$ також cooperative education (кооперативне навчання), practicum (практикум), externship (екстернат), apprenticeship (учнівство).

Стажування проводиться багатьма способами. Воно може бути оплачуваним або неоплачуваним, може проводитися в рамках навчальної програми або за бажанням, може включати академічний кредит, займати повний або неповний робочий день, відбуватися протягом літа або протягом навчального року як за межами кампусу, так і безпосередньо в ньому.

Останнім часом з'явився термін віртуальна практика (virtual internship). Віртуальна практика- це програма стажування, за якою учасник отримує досвід під час роботи у віддаленій професійній установі і фізично не присутній на робочому місці. Віртуальні інтерни можуть спілкуватися 3 роботодавцем в режимі он-лайн через різні засоби, включаючи електронну пошту, Skype, обмін миттєвими повідомленнями, телефонні розмови, вебінари, інструменти управління проектами, SMS-повідомлення тощо [8].

Віртуальні стажування проводяться як для студентів, так і для випускників. Найбільш поширені віртуальні стажування в таких галузях: інформаційні технології; розробка програмного забезпечення; маркетинг; соціальні медіа; дослідження; журналістика; ЗМI; пре- і постпланування заходів; створення та редагування відео; людські ресурси; графічний дизайн; пошукова оптимізація і маркетинг. Хоча віртуальні стажування нині рідкісні, вони стають все більш популярними через вдосконалення технологій і зростання соціальних медіа. Нині вони $є$ найбільш популярними серед малих і середніх компаній та інтернетбізнесу.

Педагогічні коледжі Голландії використовують технологію сендвіч-курсів, коли теоретичне навчання постійно поєднується з практичною діяльністю в реальних ситуаціях. В університетах Бельгії ставиться завдання перед студентами 3 курсу про пошук самостійно місць проведення практики для використання наявних знань та навичок. При цьому студенти постійно мають можливість консультуватися у своїх викладачів в університеті. У тайських університетах прийнято ставити перед студентами старших курсів серйозні завдання, які вимагають не тільки власних зусиль, а й фінансових ресурсів, які студенти повинні знайти самостійно, а також уміння мотивувати однокурсників на підготовку або реалізацію проекту [4].

Працевлаштування та набуття студентами професійних навичок супроводжують за кордоном центри розвитку кар'єри. Так, в університеті Арканзас курс «Розвиток кар'єри» пропонується кожного семестру протягом 8 тижнів. Це прискорений курс для студентів, який викладають досвідчені співробітники центру. Курс охоплює: самооцінку інтересів, цінностей та сильних сторін кандидатів, доступні сфери кар'єри, дослідження професій, створення професійного резюме, інтернет-ресурси для пошуку роботи [9]. Університет Теннессі 
пропонує студентам керівництво з розвитку кар'єри [10].

Університет Loyola в Чикаго використовує спеціальну систему Ramblerlink щодо управління кар'єрою для студентів та випускників, яка дозволяє миттєво реєструватися студентам, команді факультетів та роботодавцям [11]. До інструментів розвитку кар'єри відносяться також Going Global, який є провідним постачальником інформації щодо пошуків роботи та зайнятості. У його розпорядженні необмежений доступ до відповідної інформації 34 країн, 42 міст США, 6 міст Канади, корпоративні профілі і більш ніж 500000 місць стажування та працевлаштування в межах США та світу. До послуг студентів також медіабібліотека із записами вебінарів стосовно розвитку кар’єри, а також сервіс «Мій міст до кар'єри».

Сайт університету Північної Каролини містить розділ «Отримання досвіду», у якому наводяться відомості та приклади резюме та документів, інформація щодо стажування та екстернату, кооперативного навчання, роботи в кампусі, стратегії пошуку роботи, аналізу результатів цього пошуку, керівництво щодо пошуку роботи тощо. Центр розвитку кар'єри широко використовує у своїй діяльності Twitter, Facebook, YouTube.

Центр розвитку кар'єри в Стенфордському університеті пропонує студентам такі ресурси: рекрутинг, який допомагає студентам в інформації та організації інтерв'ю з участі роботодавців восени та взимку; ярмарки вакансій і подій, написання рекомендаційних листів, посилання на $\mathrm{PhD}$ та Postdoc дослідження. Центр розвитку кар'єри співпрацює 3 Interfolio, онлайн-сервісом управління облікових файлів коледжів і університетів. Interfolio пропонує безпечне місце для управління документами i повноваженнями, необхідними для застосування при вступі до аспірантури, робочі місця у сфері вищої освіти та інші академічні та професійні можливості [13].

Програма центру розвитку кар'єри Гарварда в галузі охорони навколишнього середовища пропонує фінансову підтримку, наставництво, побудову професійної мережі та інформацію з низки питань щодо розроблення та просуванні кар'єри в дослідженнях цієї галузі. Серед таких: індивідуальне наставництво, засоби розвитку дослідницької кар'єри, фінансова підтримка, підтримка написання грантів, соціальна допомога [12].

Отже, стажування надає цінний досвід усім його суб'єктам: студентам, викладачам коледжу чи університету, роботодавцям. Ряд закордонних університетів постійно підтримує процес стажування студентів завдяки спеціальним структурам - центрам розвитку кар'єри, які допомагають студентові в їх професійній реалізації. Інформація центрів розвитку кар'єри представлена на сайтах університетів, спеціальними інформаційними сервісами, засобами Twitter, Facebook, Youtube. Серед нових форм виробничої практики віртуальне стажування, технологія сендвіч-курсів.

Подальші дослідження пов'язані 3 розробленням методичного інструментарію для контент-аналізу сайтів українських університетів щодо інформації та сервісів, пов'язаних 3 виробничою практикою майбутніх фахівців з інформаційних технологій.

\section{Література}

1. Ільясова Ф. Проектування освітніх навчальних просторів (OLE) для підготовки фахівців ІТ-галузі / Ф. Ільясова, М. Кадиров // Вища школа. - 2013. - № 2 (104). - С. 53-59. 2. Сейдаметова 3. С. Методична система рівневої підготовки майбутніх інженерівпрограмістів за спеціальністю «Інформатика»: автореф. дис. на здобуття наук. ступеня д-ра пед. наук: 13.00.02 / 3. С. Сейдаметова ; Нац. пед. ун-т ім. М. П. Драгоманова. - Київ, 2007. 40 с. 3. Морозова Т. Перспективні напрями партнерської взаємодії між IT-освітою та ITіндустрією / Т. Морозова, І. Мендзебровський // Вища школа. - 2013. - № 5 (107). - С. 18-26. 
4. Пискунова Е. В. Зарубежный опыт в организации инновационных образовательных программ [Електронний ресурс] / Е.В.Пискунова // Universum: Вестник Герценовского университета. - 2007. - №1. - C. 19-21. - Режим доступу: http://cyberleninka.ru/ article/n/zarubezhnyy-opyt-realizatsii-innovatsionnyh-obrazovatelnyh-programm $\quad \mathbf{5}$. Положення про проведення практики студентів вищих навчальних закладів України: наказ Міністерства освіти України № 93 від 8 квітня 1993 року. 6. Усеінова Л. Ю. Формування професійнопрактичної компетентності майбутніх інженерів-педагогів в умовах виробничої практики : автореф. дисертації на здобуття наук. ступеня канд. пед. наук / Л. Ю. Усеінова. - Київ, 2010. 7. Хорошун К. В. Подготовка студентов инженерного вуза к производственной практике на основе информационных технологий / К. В. Хорошун // Вестник Московского государственного гуманитарного университета им. М. А. Шолохова. Педагогика и психология. - 2014. - № 1. - С. 80-84. 8. A White Paper: The Case for Virtual Internship [Електронний ресурс]. - Режим доступу: http://efficient-enterprises.s3.amazonaws.com/virtualinternship-white-paper/virtual-internship-white-paper.pdf 9. Career Development Center [Електронний ресурс]. - Режим доступу: http://career.uark.edu 10. Career development manual. Tennessee State University [Електронний pecypc]. - Режим доступу: http://www.tnstate.edu/careers/TennSt_CDM_12-13_Online.pdf 11. Career management system for Loyola students and graduates [Електронний pecypc].- Режим доступу: https://luccsm.symplicity.com/students/ 12. Harvard NIEHS Center for Environmental Health [Електронний peсурс]. - Режим доступу : http://www.hsph.harvard.edu/niehs/career-development/ 13. Standford Career Development Center [Електронний pecypc].- Режим доступу : https://careers.stanford.edu/ 14. What is an «internship»? [Електронний ресурс].- Режим доступу: http://polisci.osu.edu/sites/polisci.osu.edu/ files/What\%20is\%20an\%20Internship.pdf

УДК $37.014(430)$

Ірина Селищева

\section{ІСТОРИЧНА ОСВІТА В ЗАГАЛЬНООСВІТНІХ ШКОЛАХ НІМЕЧЧИНИ}

Селищева I. А. Історична освіта в загальноосвітніх школах Німеччини.

У статті розглядаються загальні підходи до історичної освіти в загальноосвітніх школах Німеччини в контексті вимог Ради Європи та з урахуванням національних традицій. 3 огляду на мету сучасної історичної освіти, сформульованої EUROCLIO, визначено ті питання, які нині залишаються відкритими і потребують розв'язання.

Ключові слова: історична освіта, підходи до навчання історії, зміст освіти, історичне критичне мислення.

Селищева И. А. Историческое образование в общеобразовательных школах Германии.

В статье рассматриваются общие подходы к историческому образованию в средних школах Германии в контексте требований Совета Европы и с учетом национальных традиций. Принимая во внимание цель современного исторического образования, сформулированную EUROCLIO, определены те вопросы, которые на сегодня остаются открытыми и требуют внимания.

Ключевые слова: историческое образование, подходы к обучению истории, содержание образования, историческое критическое мышление.

Selyshcheva I. A. History education at public schools in Germany. 